[Vol. 126:386

\title{
GOMMENTS
}

\section{THE REGULATION OF UNION POLITICAL ACTIVITY: MAJORITY AND MINORITY RIGHTS AND REMEDIES}

\section{INTRODUCTYON}

The national debate concerning the appropriate role of labor unions in American politics has, from its inception, been marked by a high degree of emotionalism. For the most part this debate has focused on the wisdom of various regulatory approaches. Although some observers feel that unions as organizations should be barred from political activity, others believe that a union's freedom of political activity should be unfettered. The polarization of views on this subject is reflected in the contradictory provisions of section 112 of the Federal Election Campaign Act (FECA) Amendments of $1976,{ }^{1}$ which regulate union political activity in federal elections.

1 Federal Election Campaign Act Amendments of 1976, Pub. L. No. 94-283, $\$ 112$, 90 Stat. 475, 486-92 (repealing 18 U.S.C. $\$ \$ 608,610$ (1970 and Supp. V 1975 )) (to be codified in 2 U.S.C. $\$ \$ 441 \mathrm{a}, 441 \mathrm{~b}$, and scattered sections of 2,26 U.S.C.). Section 112 of the 1976 Amendments, the main statutory section regulating union political conduct, provides in part:

(a) It is unlawful . . . for any corporation whatever, or any labor organization, to make a contribution or expenditure in connection with any election at which presidential and vice presidential electors or a Senator or Representative in, or a Delegate or Resident Commissioner to, Congress are to be voted for, or in connection with any primary election or political convention or caucus held to select candidates for any of the foregoing offices, or for any candidate, political committee, or other person knowingly to accept or receive any contribution prohibited by this section, or any officer or any director of any corporation or any national bank or any officer of any labor organization to consent to any contribution or expenditure by the corporation, national bank, or labor organization, as the case may be, prohibited by this section.

(b) (1) For the purposes of this section the term "Iabor organization" means any organization of any kind, or any agency or employee representation committee or plan, in which employees participate and which exists for the purpose, in whole or in part, of dealing with employers concerning grievances, labor disputes, wages, rates of pay, hours of employment, or conditions of work.

(2) For purposes of this section ... the term "contribution or expenditure" shall include any direct or indirect payment, distribution, loan, advance, deposit, or gift of money, or any services, or anything of value ... to any candidate, campaign committee, or political party or organization, in connection with any election to any of the offices referred to in this section, but shall not include (A) communications by a corporation to its stockholders and executive or administrative personnel and their families or by a labor organization to its members and their families on any subject; (B) nonpartisan registration and get-out-the-vote campaigns 
Although section 112 is cast in terms of a general prohibition of such activity, it nevertheless permits organized labor to maintain its position as one of the most powerful interest groups in American politics. $^{2}$

Unfortunately, the policy debate that has shaped the regulation of union political activity has largely obscured the fundamental question of the constitutionality of such regulation. Four competing interests are at stake: the first amendment rights of unions, the first

by a corporation aimed at its stockholders and executive or administrative personnel and their families, or by a labor organization aimed at its members and their families; and (C) the establishment, administration, and solicitation of contributions to a separate segregated fund to be utilized for political purposes by a corporation, labor organization, membership organization, cooperative, or corporation without capital stock.

(3) It shall be unlawful-

(A) for such a fund to make a contribution or expenditure by utilizing money or anything of value secured by physical force, job discrimination, financial reprisals, or the threat of force, job discrimination, or financial reprisal; or by dues, fees, or other moneys required as a condition of membership in a labor organization or as a condition of employment, or by moneys obtained in any commercial transaction;

(B) for any person soliciting an employee for a contribution to such a fund to fail to inform such employee of the political purposes of such fund at the time of such solicitation; and

(C) for any person soliciting an employee for a contribution to such a fund to fail to inform such employee, at the time of such solicitation, of his right to refuse to so contribute without any reprisal.

(4) (A) Except as provided in subparagraphs (B), (C), and (D), it shall be unlawful-

(ii) for a labor organization, or a separate segregated fund established by a labor organization, to solicit contributions to such a fund from any person other than its members and their families.

(B) it shall not be unlawful under this section for a corporation, a labor organization, or a separate segregated fund established by such corporation or such labor organization, to make 2 written solicitations for contributions during the calendar year from any stockholder, executive or administrative personnel, or employee of a corporation or the families of such persons.

(5) Notwithstanding any other law, any method of soliciting voluntary contributions or of facilitating the making of voluntary contributions to a separate segregated fund established by a corporation, permitted by law to corporations with regard to stockholders and executive or administrative personnel, shall also be permitted to labor organizations with regard to their members.

(6) Any corporation, including its subsidiaries, branches, divisions, and affiliates, that utilizes a method of soliciting voluntary contributions or facilitating the making of voluntary contributions, shall make available such method, on written request and at a cost sufficient only to reimburse the corporation for the expenses incurred thereby, to a labor organization representing any members working for such corporation, its subsidiaries, branches, divisions, and affiliates.

2 See text accompanying notes 16-17 infra. 
amendment rights of union members who oppose their union's political stance, the state's interest in dispelling corruption or the appearance of corruption, and the public's interest in receiving information. Even if the tension between the state's regulatory interest and the first amendment rights of the union is resolved, an even more delicate question remains concerning the degree to which the union's exercise of its first amendment rights may infringe upon the first amendment rights of its dissident members. ${ }^{3}$ Although these questions are analytically distinct, they are not entirely independent of one another. In fact, the rights of dissidents have been advanced as justification for regulation in this field. 4 This Comment will suggest that the interrelationship of these competing interests is helpful in understanding section 112 and in evaluating its constitutionality.

The present regulatory system was implemented partly in response to the Supreme Court's decision in Buckley v. Valeo ${ }^{5}$ and is the most explicitly detailed of Congress' attempts to regulate union political activity in federal elections. Nonetheless, confusion persists regarding what unions may legally do in the political sphere, ${ }^{6}$ despite the basic similarity between the current statute and the first statute that regulated union political activity, the War Labor Disputes Act of 1943. ${ }^{7}$ This Comment will therefore attempt to clarify what actions may be taken by union members acting through their union in the political sphere. In defining the rights of the majority, the current statute, its legislative antecedents, the interpretations the courts have applied to this legislation, and the constitutional considerations underlying the regulation of political expression will be considered. The rights and remedies of union members who disagree with their union's political stance will then be discussed. In particular, dissenters' claims that their union's political expenditures violate their first amendment rights will be considered in light of the Supreme Court's decisions in International

3 For a discussion of the state action aspects of a union's functions under a union security clause, see text accompanying notes 171-80 infra.

4 See United States v. CIO, 335 U.S. 106, 115 (1948).

5424 U.S. 1 (1976).

6 See 122 Cong. REc. S3555-3558 (daily ed. Mar. 16, 1976) (remarks of Sens. Packwood and Cannon).

7 Pub. L. No. 78-89, ch. 144, \$9, 57 Stat. 163, 167-68 (1943) (amending $\S 313$ of the Federal Corrupt Practices Act of 1925, Pub. L. No. 68-506, $\$ 313$, 43 Stat. 1070, 1074 (repealed 1948)) (current version to be codified in 2 U.S.C. $\$ 441 \mathrm{~b})$. 
Association of Machinists v. Street ${ }^{8}$ and Abood v. Detroit Board of Education. ${ }^{3}$

\section{A History of Union Political Activity}

\section{A. The Degree of Involvement}

Working people in America, banded together for mutual selfhelp, have a long history of political activity. ${ }^{10}$ The last halfcentury has witnessed the labor movement's greatest impact on American politics. Alexander Heard, a noted scholar of American campaign finance, has suggested that "[i]n some jurisdictions the guts of the politics is the competition of rival economic enterprises, the political forum replacing the market place as the arena of the free enterprise system." 11 Labor organizations now realize that the political arena, as well as the bargaining table, is a crucial forum for their interests.

As the federal government has increasingly legislated in the field of union activity and on economic matters such as wages, hours and conditions of employment which are of the most immediate concern to laboring men as workers and as union members, the necessity for labor union political activity has correspondingly increased. Today the passage or defeat of any number of bills affecting working men and their unions may be of as great importance to union members as the collective bargaining process itself. ${ }^{12}$

When unions enter the political fray, their greatest asset is not the financial resources they command, but rather "the web of personal and institutional influences by which they are linked to large numbers of people in relationships of dependence and respect." 13 Indeed, a reliance on economic force alone would place labor at a permanent disadvantage with respect to corporations, which generally have substantially greater financial resources. ${ }^{14}$

8367 U.S. 740 (1961).

997 S. Ct. 1782 (1977).

10 For a concise survey of union political activity since 1730 , see Woll, Unions in Politics: A Study in Law and the Workers' Needs, 34 S. CAL. L. Rev. 130, 144-49 (1961).

11 A. Heard, The Costs of Democracy 113 (1960).

12 Rauh, Legality of Union Political Expenditures, 34 S. CaI. L. Rev. 152, 163 (1961).

13 A. HEARD, supra note 1I, at 206.

14 In 1958 unions collected about $\$ 600$ million in dues from their members, an amount smaller than the annual after-tax profits of General Motors at that time. Id. $171 \& \mathrm{n} .8$. 
Nevertheless, the major legal controversies involving union political conduct have all focused on the use of union monies. ${ }^{15}$ The attention devoted to labor's financial impact on politics stems from the magnitude of its involvement. For example, in 1972 labor contributed $\$ 3.6$ million to the campaign coffers of congressional candidates. ${ }^{16}$ This figure represented the single largest dollar input by any broad interest group; however, it accounted for only five and two tenths percent of the contributions received by those candidates. ${ }^{17}$

Individual political contributions, coupled with contributions from groups associated with corporations, labor unions, and other organizations, as well as self-financing by candidates, and, most recently, public financing efforts, translate into the millions of dollars that are available to finance election campaigns. In 1968 these campaign expenditures reached an estimated $\$ 300$ million. ${ }^{18} \mathrm{Al}-$ though this figure may seem large in the aggregate, a partial explanation lies in the fact that Americans fill over half a million positions by means of the electoral process. ${ }^{19}$ Expenditures of such a size have been characterized as part of the inevitable "costs of democracy" needed "to expose an electorate to the views and personalities of those who through its favor seek to govern." 20

The magnitude of campaign contributions and spending naturally directs unions to maximize their financial power in the

15 See, e.g., Abood v. Detroit Bd. of Educ., 97 S. Ct. 1782 (1977); Pipefitters Local 562 v. United States, 407 U.S. 385 (1972); United States v. UAW, 352 U.S. 567 (1957); United States v. CIO, 335 U.S. 106 (1948).

16 I Common Cause, 1972 Federat Campatgn Finances, Interest Groups and Poutrical Parties, at vi (1974). Congressional candidates in 1972 received contributions totalling $\$ 69.7$ million. $I d$. at iv. Of these contributions, $\$ 16.6$ million came from special interest contributors and political party committees, id. at $v$, with $\$ 3.6$ million originating with labor affiliated groups and $\$ 3.4$ million originating with business, agricultural, and health organizations. Id. at vi.

17 For a discussion of the major sources of labor affiliated contributions, some leading recipients, and certain patterns of giving, see $2 i d$. at $x$-xi.

The disparity between the enormity of labor's role in absolute terms and its more modest role in comparative terms can be explained by the propensity of Americans in the second half of the $20 \mathrm{kh}$ century to participate in politics in a variety of ways in addition to voting, such as signing petitions, engaging in political discussions, ringing doorbells for candidates, and contributing to campaign coffers. Senate Subcomm. on Intergovernmental Relations of the Comm. on Government Operations, 93d Cong., lst Sess., Confidence and Concern: Cimizens VIEW AMERICAN Governament, pt. I, 256 (1973). Today the proffering of campaign contributions constitutes an important act of political expression for many. According to a survey commissioned by the Senate in the aftermath of Watergate, 33\% of all Americans 18 years of age and older have contributed to a political campaign at one time or another. Id. 256.

18 H. Alexander, Political Financing 38 (1972).

19 A. HEARD, supra note 11 , at 8.

$20 I d$. 
political arena. For example, a union may undertake an educational campaign to induce union members who might otherwise have remained inactive to make a political contribution, ${ }^{21}$ Another obvious method of increasing political effectiveness is to aggregate large numbers of small contributions. ${ }^{22}$ The fear of aggregated wealth, however, originally prompted the regulation of corporate political activity-a form of regulation that has since been applied in equal measure to labor unions. ${ }^{23}$

\section{B. Regulation and Interpretation: Congress and the Supreme Court}

\section{The Early Statutes}

In a message to the Wisconsin legislature in 1905, Governor Robert M. LaFollette condemned the pernicious effect of corporate intrusions into politics:

The participation in government of the corporation as a corporation is a menace. Its action is governed by no sense of individual or personal responsibility. It is controlled by no sentiment of patriotism. Corporations are organized for profit and gain, and enter the field of politics solely in the interests of the business for which they are created. ${ }^{24}$

Similar fears and resentments caused Congress to exercise its prima facie power to regulate the conduct of federal elections ${ }^{25}$ in enacting the Tillman Act of $1907 .{ }^{26}$ The twin legislative purposes of com-

21 Id. 110.

22 Twentueth Century Fund, Electing Congress 66-67 (1970).

23 See United States v. CIO, 335 U.S. 106, 113 (1948).

24 State v. Joe Must Go Club, 270 Wis. 108, 111, 70 N.W.2d 681, 682 (1955) (emphasis in original), quoted in Comment, Civil Responsibility for Corporate Political Expenditures, 20 U.C.L.A. L. Rev. 1327, 1331 n.25 (1973).

25 For a discussion of Congress' prima facie power in this area, see A. Rosenthat, Federal Regulation of Campajge Finance: Some Constitutional QuesTIONS 12-19 (1972); Comment, The Constitutionality of Restrictions on Individual Contributions to Candidates in Federal Elections, 122 U. PA. L. REv. 1609, 1614-16 (1974). Article I, $\$ 4$ of the Constitution authorizes the congressional oversight of elections for United States senators and representatives. Although Congress' power was at one time understood not to apply to the party nomination process, Newberry v. United States, 256 U.S. 232 (1921), the way to the congressional regulation of this process was opened by United States v. Classic, 313 U.S. 299 (1941). Even in the absence of an explicit constitutional grant of authority, the Supreme Court has found that Congress is empowered to regulate presidential elections as well. Burroughs v. United States, 290 U.S. 534, 545 (1934). Congress' power to regulate federal elections was most recently reaffirmed in Buckley v. Valeo, 424 U.S. I, 13-14 \& n.16 (1976).

26 Pub. L. No. 59-36, 34 Stat. 864 (1907) (current version to be codified in 2 U.S.C. $\$ 441 b)$. 
batting corporate influence over federal elections and protecting shareholders from having their funds expended for political purposes without their consent were reflected in the Act, ${ }^{27}$ which prohibited corporate money contributions in connection with a federal election. ${ }^{28}$ Such a legislative approach was necessitated by the absence of any common law authority that barred corporations from making political contributions. ${ }^{29}$

Congress' next major effort in this area was the enactment of section 313 of the Federal Corrupt Practices Act of 1925.30 Although section 313 retained the spirit and most of the wording of the Tillman Act's prohibition, it broadened the definition of "contribution" to include "a gift, subscription, loan, advance, or deposit, of money, or anything of value, and includes a contract, promise, or agreement, whether or not legally enforceable, to make a contribution." 31

Following the outbreak of World War II, Congress turned its attention to the political activities of unions:

The need for unprecedented economic mobilization propelled by World War II enormously stimulated the power of organized labor and soon aroused consciousness of its power outside its ranks. Wartime strikes gave rise to fears of the new concentration of power represented by the gains of trade unionism. And so the belief grew that, just as the great corporations had made huge political contributions to influence governmental action or inaction, whether consciously or unconsciously, the powerful unions were pursuing a similar course, and with the same untoward consequences for the democratic process. ${ }^{32}$

27 See United States v. CIO, 335 U.S. 106, 113 (1948).

28 The Act provided in relevant part:

That it shall be unlawful for any national bank, or any corporation organized by authority of any laws of Congress, to make a money contribution in connection with any election to any political office. It shall also be unlawful for any corporation whatever to make a money contribution in connection with any election at which Presidential and Vice-Presidential electors or a Representative in Congress is to be voted for or any election by any State legislature of a United States Senator.

Pub. L. No. 59-36, 34 Stat. 864, 865 (1907) (current version to be codified in 2 U.S.C. $\$ 441 \mathrm{lb})$. 547 (1974).

29 See Comment, Corporate Campaign Funding, 4 Cum.-SaMr. L. Rev. 544, 30 Pub. L. No. 68-506, §313, 43 Stat. 1070, 1074 (1925) (repealed 1948)

(current version to be codified in 2 U.S.C. $\$ 441 \mathrm{~b}$ ).

31 Id. $\$ 302(\mathrm{~d}), 43$ Stat. $1070,1071$.

32 United States v. UAW, 352 U.S. 567, 578 (1957). 
Congress responded by passing the War Labor Disputes Act of $1943{ }^{33}$ which contained a provision extending the prohibitions applicable to corporate political activity in federal elections to labor unions for the duration of the war. Just as the regulation of corporate political activity was designed to curb the influence of aggregated wealth ${ }^{34}$ and to protect minority shareholders from having their funds expended for political purposes without their consent, so was this Act designed to achieve the same results with regard to unions. ${ }^{35}$ In committee hearings, Representative Landis, the sponsor of a portion of the Act, asserted that labor unions and corporations should be placed on an equal footing with respect to the federal regulation of their political activity:

The public thinks, and has a right to think, that labor unions, as public institutions should be granted the same rights and no greater rights than any other public group. My bill seeks to put labor unions on exactly the same basis, insofar as their financial activities are concerned, as corporations have been on for many years. ${ }^{36}$

This equation of corporations and labor unions remains a hallmark of the federal regulation of elections to this day. ${ }^{37}$

After the war, Congress adopted the Labor Management Relations (Taft-Hartley) Act of 1947.38 In amending section 313 of Federal Corrupt Practices Act, section 304 of Taft-Hartley permanently applied to unions the same ban on political contributions in federal elections that applied to corporations. In addition, section 313 of the Federal Corrupt Practices Act was revised to ban expenditures as well as contributions. ${ }^{39}$ The presidential election of 1944 revealed that the word "contribution" was easily circumvented; unions played a major financial role in various elections

33 Pub. L. No. 78-89, ch. 144, 99,57 Stat. 163, 167-68 (1943) (current version to be codified in 2 U.S.C. $\$ 44 I \mathrm{~b})$.

34 See S. Rep. No. 101, 79th Cong., Ist Sess. 24 (1945); To Regulate Labor Organizations: Hearings on H.R. 804 and H.R. 1483 Before a Subcomm. of the House Comm. on Labor, 78th Cong., Ist Sess. 2 (1943) [hereinafter cited as Hearings] (statement of Rep. Landis).

35 See Hearings, supra note 34, at 117-18, 133; 89 CoNG. REc. 5334 (remarks of Rep. Halleck), 5792 (remarks of Sen. Revercomb) (1943).

36 Hearings, supra note 34, at 1.

37 See Federal Election Campaign Act Amendments of 1976, Pub. L. No. 94-283, $\$ 112,90$ Stat. $475,490-92$ (to be codified in 2 U.S.C. $\$ \$ 441 \mathrm{a}, 441 \mathrm{~b}$, and scattered sections of 2,26 U.S.C.).

38 Labor Management Relations (Taft-Hartley) Act of 1947, Pub. L. No. 80101, 61 Stat. 136 (codified at 29 U.S.C. $\$ \$ 141-88$ ) (1970 \& Supp. V 1975).

3918 U.S.C. $\$ 610$ (1970 \& Supp. V 1975) (repealed 1976) (current version to be codified in 2 U.S.C. $\$ 441 \mathrm{~b})$. 
through indirect contributions, such as the publication of newspapers and advertisements on behalf of selected candidates. ${ }^{40}$ By banning expenditures as well as contributions, Congress sought to fulfill more adequately the purposes of the Act. ${ }^{41}$

\section{The Supreme Court Decisions}

Few cases arose under the Federal Corrupt Practices Act prior to the inclusion of unions within the statutory ban. Nearly all of the major cases under this statute or the relevant sections of FECA and its amendments that have reached the Supreme Court have involved labor unions. Despite invitations to decide these cases on constitutional grounds, the Court has consistently declined to do so. Although this approach has evoked vociferous criticism, ${ }^{42}$ the resulting construction of the statutes has more exactingly defined the demarcation between permissible and impermissible union political conduct.

In the first of these cases, United States $v . C I O,{ }^{43}$ the Court considered an indictment charging the CIO and its president with a violation of section 313 of the Federal Corrupt Practices Act, as amended by section 304 of the Taft-Hartley Act, for having published and distributed an issue of The CIO News, an organ owned and published at union expense. The paper contained an editorial advocating the election of a candidate in a special congressional election in Maryland. The district court found this activity to be of the very type that Congress had prohibited. ${ }^{44}$ Finding no "clear and present danger to the public interest," however, the court held the provision to be an abridgement of first amendment rights and dismissed the indictments. ${ }^{45}$

The Supreme Court affirmed the district court's dismissal of the indictments, but its opinion was based on nonconstitutional grounds. The Court asserted:

If $\S 313$ were construed to prohibit the publication, by corporations and unions in the regular course of conduct-

40 See 93 Cong. Rec. 6436-39 (1947); Hearings, supra note 34, at 23-24.

41 See United States v. CIO, 335 U.S. 106, 115 (1948).

${ }^{42}$ See, e.g., United States v. UAW, 352 U.S. 567, 595-98 (1957) (Douglas, J., dissenting); United States v. CIO, 335 U.S. 106, 139-40 (1948) (Rutledge, J., concurring); Cohan, Of Politics, Pipefitters, and Section 610: Union Political Contributions in Modern Context, 51 TEx. L. Rev. 936, 942-43 (1973).

43335 U.S. 106 (1948).

44 United States v. CIO, 77 F. Supp. 355, 357 (D.D.C.), aff'd on other grounds, 335 U.S. 106 (1948).

45 Id. $357-58$. 
ing their affairs, of periodicals advising their members, stockholders or customers of danger or advantage to their interests from the adoption of measures, or the election to office of men espousing such measures, the gravest doubt would arise in our minds as to its constitutionality. ${ }^{46}$

Unlike the district court, the Supreme Court found that the Act was not intended to apply to an expression of the union's political views in a regularly published union newspaper whose distribution was limited substantially to union members. This conclusion was based on the Court's reading of the Act's legislative history. ${ }^{47}$ Justice Rutledge, in a concurring opinion, found the Court's construction to be untenable, asserting that the statute as applied was "patently invalid" as a "sweepingly comprehensive" restriction on first amendment rights. ${ }^{48}$

The Court's statutory construction in $C I O$ nevertheless avoided the necessity of ruling on the constitutionality of the statute. ${ }^{49}$ In construing the statute, the Court sought to implement the original purposes of section 313: restricting the influence of aggregated wealth over elections and prohibiting the involuntary use of potential dissenters' funds for political purposes.50 In the wake of $C I O$, the lower courts followed the Supreme Court's lead in construing the statute narrowly; ${ }^{5 x}$ but in the next major case concerning union political activity that reached the Supreme Court, United States v. $U A W,{ }^{52}$ the Court held that the union's conduct did violate the statute. The UAW was charged with using union dues to finance

46335 U.S. at 121.

47 Id. 115-21. infra.

$48 \mathrm{Id}$. 130, 132 (Rutledge, J., concurring); see text accompanying notes 106-10

49 Id. 124.

s0 Id. 113.

51 In United States v. Painters Local 481, 172 F.2d 854 (2d Cir. 1949), the court reversed the conviction of a union president who, with the authorization of a special membership meeting, paid $\$ 111.14$ for a political advertisement in a daily newspaper and $\$ 32.50$ for a radio broadcast with funds from the general treasury. The court found it impossible to distinguish CIO, holding that because the union owned no newspaper, its expenditures were the natural way to communicate its views to its members and thus were not prohibited by the statute. Similarly, in United States v. Construction \& General Laborers Local 264, 101 F. Supp. 869 (W.D. Mo. 1951), the court found that the union's payment of compensation to three employees, a large portion of whose services involved political activities, did not violate the Act. The court noted the "uncertain, insignificant amount" of the expenditure involved, $i d$. 873 , and concluded that if the union's activities were prohibited "any political activity of any person on the payroll of a labor organization, from its president to its janitor, would render that Union and its principal officers liable." Id. 876.

52352 U.S. 567 (1957). 
television broadcasts that were intended to influence congressional elections. Distinguishing $C I O$, the Supreme Court remanded to the district court for trial:

[U]nlike the union-sponsored political broadcast alleged in this case, the communication for which the defendants were indicted in C.I.O. was neither directed nor delivered to the public at large. The organization merely distributed its house organ to its own people. The evil at which Congress has struck in $\S 313$ is the use of corporation or union funds to influence the public at large to vote for a particular candidate or a particular party.53

As in CIO, the Court relied upon its interpretation of the statute's legislative history ${ }^{54}$ to support the conclusion that the union's conduct was "precisely the kind of indirect contribution . . . that Congress amended $\$ 313$ to proscribe." 55

The $U A W$ Court again declined to rule on the statute's constitutionality, asserting that any potential constitutional issue needed to be developed in the first instance at the trial level. ${ }^{56}$ Justice Frankfurter, writing for the majority, did, however, suggest several tests by which the statutory issues involved could be approached:

[W] as the broadcast paid for out of the general dues of the union membership or may the funds be fairly said to have been obtained on a voluntary basis? Did the broadcast reach the public at large or only those affiliated with [the union]? Did it constitute active electioneering or simply state the record of particular candidates on economic issues? Did the union sponsor the broadcast with the intent to affect the results of the election? ${ }^{57}$

The effect of the $C I O$ and $U A W$ opinions was to prescribe a case by case approach for the regulation of union political activity based upon the Court's reading of the statutory language, while avoiding any underlying constitutional difficulties. In the 1970's, however, Congress again turned its attention to the regulation of

53 Id. 589 (emphasis supplied).

54 Id. 577-88.

55 Id. 585.

56 Id. $591-92$.

57 Id. 592. Lower courts in turn have used these tests as indices of statutory violations. See, e.g., United States v. Lewis Food Co., 236 F. Supp. 849, 853 (S.D. Cal. 1964); United States v. Anchorage Central Labor Council, 193 F. Supp. 504, 506 (D. Alas. 1961). 
political activity by the passage of the Federal Election Campaign Act of $1971^{58}$ and subsequent amendments. ${ }^{59}$

\section{The New Regulatory Scheme: The Federal Election} Campaign Act and Amendments

Congress again addressed the regulation of campaign financing in enacting the Federal Election Campaign Act of 1971. Section 205 of the 1971 Act amended the definition of prohibited expenditures in section 610 of title 18 of the United States Code to exclude specifically from the prohibition

communications by a corporation to its stockholders and their families or by a labor organization to its members and their families on any subject; nonpartisan registration and get-out-the-vote campaigns by a corporation aimed at its stockholders and their families, or by a labor organization aimed at its members and their families; the establishment, administration, and solicitation of contributions to a separate segregated fund to be utilized for political purposes by a corporation or labor organization. ${ }^{60}$

Representative Hansen, the sponsor of this amendment, stated during congressional debate that the purpose of his amendment was "to codify and clarify the existing law and not to make any substantive changes in the law." 61

The issue of voluntary contributions to a separate political fund was addressed by the Supreme Court in Pipefitters Local 562 v. United States. ${ }^{62}$ In Pipefitters the defendant union and three of its officers were convicted of conspiracy to violate section 610 in regard to the expenditure of funds in a federal political campaign.

58 Federal Election Campaign Act of 1971, Pub. L. No. 92-225, 86 Stat. 3 (codified at 2 U.S.C. $\$ \$ 431-454$ (Supp. V 1975)). For a discussion of the major provisions of the Act, see Comment, Campaign Finance Acts-An Attempted Balance Between Public Interests and Individual Freedoms, 24 U. KaN. L. Rev. 345, 368 (1976).

50 The Act was amended in 1974, see text accompanying notes 68-71 infra, and in 1976, see text accompanying notes 76-82 infra.

60 Pub. L. No. 92-225, $\$ 205,86$ Stat. 10, 18 U.S.C. $\$ 610$ (Supp. II 1972 \& Supp. V 1975) (repealed 1976) (current version to be codified in 2 U.S.C. $\$ 441 \mathrm{~b}$ ).

61118 Cong. Rec. 328 (1972) (remarks of Rep. Hansen). See Pipefitters Local 562 v. United States, 407 U.S. 385, 423-26 (1972).

62407 U.S. 385 (1972). The union had collected a fund of $\$ 1,230,968$ between 1963 and 1968. United States v. Pipefitters Local 562, 434 F.2d 1116, 1121 (8th Cir.), affd on rehearing, 434 F.2d 1127 (8th Cir. 1970) (en banc), 1єن'd, 407 U.S. 385 (1972). 
The Supreme Court reversed the convictions, however, because of an erroneous jury instruction concerning the voluntariness of the contributions. ${ }^{63}$

The Pipefitters test required that union funds for political purposes must be voluntarily contributed and kept separate from general union monies:

We hold that such a fund must be separate from the sponsoring union only in the sense that there must be a strict segregation of its monies from union dues and assessments. We hold, too, that, although solicitation by union officials is permissible, such solicitation must be conducted under circumstances plainly indicating that donations are for a political purpose and that those solicited may decline to contribute without loss of job, union membership, or any other reprisal within the union's institutional power. ...

$[T]$ he test of voluntariness under $\$ 610$ focuses on whether the contributions solicited for political use are knowing free-choice donations. The dominant concern in requiring that contributions be voluntary was, after all, to protect the dissenting stockholder or union member. Whether the solicitation scheme is designed to inform the individual solicited of the political nature of the fund and his freedom to refuse support is, therefore, determinative. ${ }^{64}$

The Court did not ignore the congressional purpose of mitigating the effect of aggregated wealth on elections, but stressed that the wealth Congress had in mind was "the general union Treasurynot the funds donated by union members of their own free and knowing choice." ${ }^{65}$ The Court labelled as a "misapprehension" 60 the idea that Congress intended to ban the aggregation and expenditure of members' voluntary contributions, while reaffirming that "an indictment that alleges a contribution or expenditure from the general treasury of a union or corporation in connection with a federal election states an offense." 67 As in $C I O$ and $U A W$, the

63407 U.S. at $399-400$.

64 Id. 414-15 (footnote omitted).

65 Id. 416.

66 Id. $415-16$ n.28.

$67 \mathrm{Id}$. The Court stated, without deciding the issue, that the unanimous vote of union members or stockholders of a corporation may at most be a defense to such a contribution from general funds. Id. 
Supreme Court did not pass on the constitutionality of the statutory system for the regulation of union political activity.

When the abuses of Watergate became public, Congress overhauled the system for regulating federal elections by the passage of the Federal Election Campaign Act Amendments of $1974{ }^{68}$ which "clamped tight restrictions with appropriate enforcement provisions upon campaign finances." 69 Although the scope of the 1974 Amendments was sweeping, ${ }^{70}$ the basic structure regulating union political activity was not altered. No aggregate limitation on contributions by organizations was imposed as had been done in the case of individuals, nor were expenditure limitations imposed on organizations. These omissions allowed organizations, such as a union political action committee, to retain great freedom of political action if resources were available. ${ }^{71}$

The Amendments faced a major challenge in Buckley $v$. Valeo. ${ }^{72}$ The Supreme Court found that although the provisions limiting campaign contributions met constitutional scrutiny, the 1974 Amendments' ceilings on independent expenditures, overall campaign expenditures, and candidates' personal expenditures were impermissible infringements on political speech. ${ }^{73}$ Moreover, the Court held that the Federal Election Commission was unconstitutionally formulated. ${ }^{74}$ Nothing in the Court's opinion directly

${ }^{68}$ Federal Election Campaign Act Amendments of 1974, Pub. L. No. 93-443, 88 Stat. 1263 (codified in scattered sections of $2,5,18,26$ U.S.C.).

69 Comment, Campaign Finance Acts-An Attempted Balance Between Public Interests and Individual Freedoms, 24 U. KAN. L. Rev. 345, 369 (1976).

70 Among other items, the 1974 Amendments contained the following provisions: contributions by individuals were limited to $\$ 1,000$ per candidate for federal office with a total contribution ceiling of $\$ 25,000$ yearly, for all candidates; expenditures by an individual "relative to a clearly identified candidate" were limited to $\$ 1,000$ per year; the amount of personal funds that could be spent by candidates in their own campaigns was limited; total expenditure limits for federal campaigns were specified; cash contributions in excess of $\$ 100$ and contributions from foreign countries were banned; reporting and disclosure requirements were strengthened; the Federal Election Commission, with responsibility for oversight of the Act and with civil enforcement powers, was created; and a public financing system for presidential contests was elaborated. Federal Election Campaign Act Amendments of 1974, Pub. L. No. 93-443, \$101, 88 Stat. 1263. Several of these provisions were repealed or amended by the FECA Amendments of 1976. Federal Election Campaign Act Amendments of 1976, Pub. L. No. 94-283, 90 Stat. 475 (to be codified in scattered sections of 2, 26 U.S.C.). See text accompanying notes 76-82 infra.

71 See Buckley v. Valeo, 424 U.S. 1, 28-29 n.31 (1976).

72424 U.S. 1 (1976).

73 Id. 58-59.

74 Id. 43. 
addressed the statutory framework regulating union political activity, however. ${ }^{75}$

In direct response to Buckley, ${ }^{76}$ Congress redrafted the Federal Election Campaign Act to pass constitutional muster. The resulting Federal Election Campaign Act Amendments of 1976 reconstituted the Federal Election Commission, ${ }^{77}$ maintained the individual contribution limitations for federal elections at $\$ 1,000$ per candidate with an aggregate maximum of $\$ 25,000,{ }^{78}$ removed candidate expenditure limits and ceilings on individual expenditures relative to a particular candidate, ${ }^{79}$ and maintained the limitation of $\$ 5,000$ that a multi-candidate political committee may contribute to a candidate for federal office. ${ }^{80}$ No overall committee contribution ceilings were established.

The 1976 Amendments to FECA repealed the sections of title 18 of the United States Code that regulated union political activity and recodified the provisions in amended form. Although the general ban on the use of corporate and union funds is retained, ${ }^{81}$ the Amendments describe with greater specificity the exceptions to that general ban. ${ }^{82}$

75 For a discussion of Buckley's implications for the constitutionality of the regulatory scheme embodied in new $\$ \$ 441 \mathrm{a}$ and $44 \mathrm{lb}$ of tit. 2 of the United States Code, see text accompanying notes 120-35 infra.

76 See, e.g., S. Rep. No. 94-677, 94th Cong., 2d Sess. 1-2, reprinted in [1976] U.S. Code Cong. \& Ad. News 929-30.

77 Federal Election Campaign Act Amendments of 1976, Pub. L. No. 94-283, $\$ 101$, 90 Stat. $475,475-477$ (amending 2 U.S.C. $\$ 437$ (Supp. IV 1974)) (to be codified in 2 U.S.C.).

${ }^{78}$ Id. $\$ 112,90$ Stat. 475,487 (to be codified in 2 U.S.C. $\$ 441 a$ ).

79 Id. $\$ 201,90$ Stat. $475,496$.

80 Id. $\$ 112,90$ Stat. 475,487 (to be codified in 2 U.S.C. $\$ 441 b$ ). The Amendments define a multicandidate political committee as one that "has been registered under section 303 for a period of not less than 6 months, which has received contributions from more than $\mathbf{5 0}$ persons, and, except for any State political party organization, has made contributions to 5 or more candidates for Federal office." Id.

The 1976 Amendments state that all contributions made by political committees established by an organization will be considered to have been made by a single committee. The legislative history of the Amendments clearly shows Congress' intent with respect to this provision: "The anti-proliferation rules established by the conference substitute are intended to prevent corporations, labor organizations, or other persons or groups of persons from evading the contribution limits of the conference substitute." House CoN. REP. No. 94-1057, at 58, 94th Cong., 2d Sess. (1976), reprinted in [1976] U.S. Code Cong. \& AD. News 946, 973.

81 Federal Election Campaign Act Amendments of 1976, Pub. L. No. 94-283, $\$ 112,90$ Stat. 475,490 (to be codified in 2 U.S.C. $\$ 441 \mathrm{~b}$ ).

82 Id., 90 Stat. 475,491 (to be codified in 2 U.S.C. $\$ 441 \mathrm{~b}$ ). 


\section{Permissible Union Political Activity}

As a result of the framework created by the FECA Amendments of 1976 and by pre-existing case law and state regulations, unions may engage in the following activities with general treasury funds:

(1) communicate with union members and their families on any subject whatever; ${ }^{83}$

(2) conduct registration and get-out-the-vote drives aimed at members and their families; ${ }^{84}$

(3) if not prohibited by state law, ${ }^{85}$ make contributions to and expenditures supporting state and local candidates ${ }^{86}$ and in connection with state and local referenda; ${ }^{37}$

(4) expend funds aimed at the general public in an educational campaign; 88

(5) establish, administer, and solicit contributions to a separate, voluntary political fund. ${ }^{39}$

The requirement for a separate fund may be met by "a strict segregation of [the fund's] monies from union dues and assessments." 90 The union leadership is free to direct the fund and

83 Id., 90 Stat. 475 (to be codified in 2 U.S.C. $\$ 44 \mathrm{Ib}$ ). Active electioneering directed at members and their families is clearly permitted. See, e.g., United States v. CIO, 335 U.S. 106 (1948); United States v. Boyle, 338 F. Supp. 1028, 1033 (D.D.C. 1972).

84 Federal Election Campaign Act Amendments of 1976, Pub. L. No. 94-283, $\$ 112,90$ Stat. 475,491 (to be codified in 2 U.S.C. $\$ 441 \mathrm{~b}$ ).

85 For a list of states that regulate or prohibit corporate and union contributions, see National Association of Attorney Generals, Legislative Approaches to Campatgn Finance 16-17 (1974).

80 Section 44lb of tit. 2 of the United States Code will leave open to unions and corporations the possibility of contributing directly to nonfederal campaigns from general union or corporate funds. Federal candidates who run on the same ticket with the nonfederal candidates will be indirectly benefited by such contributions; in addition, these contributions may release funds to aid those candidates for federal office in other respects. Rauh, Legality of Union Political Expenditures, 34 S. CAI. L. Rev. 152, 152-53 (1961); A. Heard, supra note 11, at 200.

87 See DeMille v. American Fed'n of Radio Artists, 31 Cal. 2d 139, 187 P.2d 769 (1947), cert. denied, 333 U.S. 879 (1948).

88 The prohibitions of $\$ 112$ of the FECA Amendments of 1976 are applicable with regard to union political activity only in connection with party conventions or caucuses, primary elections, or general elections for federal offices. Pub. L. No. 94-283, $\$ 112,90$ Stat. 475,491 (to be codified in 2 U.S.C. $\$ \$ 441 \mathrm{a}, 441 \mathrm{~b}$ ). The statute would not prohibit, for example, a union educational campaign aimed at creating public support for the repeal of all legislation regulating union political activity or lobbying efforts toward the same end.

so Id.

90 Pipefitters Local 562 v. United States, 407 U.S. 385, 414 (1972). 
solicit contributions to it. ${ }^{91}$ In an effort to allay fears concerning the use of coercive solicitation techniques by the union, title 2 specifically dictates that any person who solicits contributions to a fund must inform the potential donor of the political purposes of the fund and of the option to refuse to contribute without any reprisal. ${ }^{92}$

With the same general treasury funds, a union may not:

(1) make any contribution in connection with a federal election; ${ }^{93}$

(2) make expenditures in connection with a federal candidate if such expenditures are directed at the general public; ${ }^{34}$

(3) accept or expend coerced contributions to a separate political fund..$^{95}$

If a union establishes a separate, voluntary political fund, the union may legally:

(1) contribute up to $\$ 5,000$ per candidate for federal office and up to $\$ 15,000$ to a national party committee; ${ }^{96}$

(2) make independent expenditures 97 of an unlimited amount, including active electioneering aimed at the general public; ${ }^{\text {s }}$

(3) use the fund for any purpose permitted to the general union treasury fund.

\section{Id.}

92 Federal Election Campaign Act Amendments of 1976, Pub. L. No. 94-283, $\S 112,90$ Stat. 475,491 (to be codified in 2 U.S.C. $\$ 44 \mathrm{lb}$ ).

93 Id., 90 Stat. $475,490$.

94 Id. "The evil at which Congress has struck ... is the use of corporation or union funds to influence the public at large to vote for a particular candidate or a particular party." United States v. UAW, 352 U.S. 567, 589 (1957) (emphasis supplied).

95 Pipefitters Local 562 v. United States, 407 U.S. 385, 414 (1972).

96 Federal Election Campaign Act Amendments of 1976, Pub. L. No. 94-283, $\$ 112,90$ Stat. 475,487 (to be codified in 2 U.S.C. $\$ 441 \mathrm{a}$ ).

97 " $[I]$ ndependent expenditure means an expenditure by a person expressly advocating the election or defeat of a clearly identified candidate which is made without cooperation or consultation with any candidate or any authorized committee or agent of such candidate and which is not made in concert with, or at the request or suggestion of, any candidate . ...'Id. $\$ 101,90$ Stat. 475, 479 .

98 Although the "evil" pinpointed by the Court in $U A W$ referred to unionfinanced electioneering that was aimed at the general public, note 94 supra, the Court in Pipefitters made clear that the prohibition applied only to funds from the union's general treasury and not to funds voluntarily contributed to a "separate segregated political fund." 407 U.S. at $415-16$ \& n.28. 
Although the regulatory scheme that Congress has devised to oversee federal elections is significantly more complex than the Tillman Act of 1907, the language and objectives of that Act remain central to the present system. The general rule as enacted by Congress and construed by the courts is that corporations and unions are barred from making contributions or expenditures from their general funds with regard to a federal election. In this way, the danger of aggregated wealth is partly addressed. That this ban is not total, however, is evidenced by the authorization of separate political funds financed by voluntary contributions. The requirement that such contributions must be voluntary and made with knowledge of the purpose of the fund and absent any threat of reprisal embodies the concern for protecting minority union members from having their funds expended for political purposes to which they do not subscribe. The two original purposes for Congress' regulation in this area are thus both maintained in the present system; but questions persist concerning the constitutionality of the statute's prohibition on the use of general treasury funds for political purposes.

\section{Constitutional Considerations in the Regulation} of Union Political Activity

\section{A. The Grounds for a Constitutional Attack}

The regulation of political activity inevitably raises serious questions of constitutionality. "Discussion of public issues and debate on the qualifications of candidates are integral to the operation of the system of government established by our Constitution." 90 Contribution and expenditure limitations with regard to federal elections have been held to "operate in an area of the most fundamental First Amendment activities." 100 If the sole concern in the area of union political activities were to avoid any possibility of impinging even peripherally on rights protected by the first amendment, that could be accomplished simply by deregulating all such activities. ${ }^{101}$ This approach, however, would constitute a complete abdication by Congress of its obligation to remedy the evils that

99 Buckley v. Valeo, 424 U.S. 1, 14 (1976).

$100 \mathrm{Id}$. For a discussion of the implications of Buckley for the regulation of campaign contributions and expenditures by individuals, see the sources cited in Note, The Unconstitutionality of Limitations on Contributions to Political Committees in the 1976 Federal Election Campaign Act Amendments, 86 Y ALE L.J. 953, 953 n.I (1977).

101 See Comment, Corporate Campaign Funding, 4 CuM.-SaM. L. REv. 544, $559-60$ (1974). 
originally prompted the passage of the Tillman Act. Instead, it is necessary to examine how the union's freedom of speech conflicts with the need to protect the integrity of the political system on the one hand, and the rights of individual union members on the other.

As individuals, union members share all of the political rights enjoyed by all other citizens, including the freedom to associate for the common advancement of political beliefs. ${ }^{102}$ Although corporations and unions as entities are not entitled to enjoy all the rights and guarantees of liberty provided by the Constitution, ${ }^{103}$ they are guaranteed the freedom of speech. ${ }^{104} \mathrm{~A}$ constitutional analysis of regulation in this area also requires a consideration of the interests of the public in receiving political speech because one goal of the first amendment is the creation of "an informed public capable of conducting its own affairs." 105

A concern for the first amendment interests of union members in association, unions as organizations, and the public at large has led many observers to conclude that the system of regulating union political activity is unconstitutional. The most authoritative arguments to that effect have come from the Supreme Court itself. In CIO, Justice Rutledge in concurrence argued that the Court's dismissal of the indictments should be based not on statutory construction, but on the patent unconstitutionality of the statute. ${ }^{106}$ Displaying a sweeping belief in the tenets of pluralism, he extolled the benefits of bloc representation, ${ }^{\mathbf{1 0 7}}$ which were presumably furthered by union political activity. After citing the need for narrowly drawn statutes when first amendment freedoms are involved, ${ }^{108}$ Justice Rutledge found "no showing, legislative or otherwise, of corruption so widespread or of 'undue infuence' so dominating as

102 Buckley v. Valeo, 424 U.S. I, 57 (1976); Kusper v. Pontikes, 414 U.S. 51, 56-57 (1973); NAACP v. Button, 371 U.S. 415,430 (1963); NAACP v. Alabama, 357 U.S. 449,460 (1958).

103 United States v. White, 322 U.S. 694 (1944) (constitutional privilege against self-incrimination not applicable to unions); Western Turf Ass'n v. Greenberg, 204 U.S. 359 (1907) (corporation not protected against impairment by state law of privileges and immunities of citizens of United States).

104 See Food Employees Local 590 v. Logan Valley Plaza, Inc., 391 U.S. 308 (1968) (held overruled on other grounds by Lloyd Corp. v. Tanner, 407 U.S. 551 (1972), in Hudgens v. NLRB, 424 U.S. 507 (1976)) (unions); NLRB v. Fruit \& Vegetable Packers Local 760, 377 U.S. 58, 76 (1964) (Black, J., concurring) (unions); New York Times Co. v. Sullivan, 376 U.S. 254 (1964) (corporations); Grosjean v. American Press Co., 297 U.S. 233 (1936) (corporations); Schwartz v. Romnes, 495 F.2d 844 (2d Cir. 1974) (corporations).

105 Red Lion Broadcasting Co. v. FCC, 395 U.S. 367, 392 (1969); see C \& C Plywood Corp. v. Hanson, 420 F. Supp. 1254 (D. Mont. 1976).

106335 U.S. 106, 129 (1948) (Rutledge, J., concurring).

${ }_{107}$ Id. 143-44 (Rutledge, J., concurring).

108 Id. 141-42 (Rutledge, J., concurring). 
could possibly justify so absolute a denial of these basic rights." 109 His view of the statute's unconstitutionality derived in part from his analysis of its pernicious effect on the political system:

There is therefore an effect in restricting expenditures for the publicizing of political views not inherently present in restricting other types of expenditure, namely, that it necessarily deprives the electorate, the persons entitled to hear, as well as the author of the utterance, whether an individual or a group, of the advantage of free and full discussion and of the right of free assembly for that purpose. ${ }^{110}$

In his dissent in $U A W$, Justice Douglas cited Justice Rutledge's opinion in CIO with approval, finding the regulatory scheme as construed and applied to be "a broadside assault on the freedom of political expression guaranteed by the First Amendment." 111 Although he acknowledged that Congress may regulate contributions under certain circumstances, ${ }^{112}$ Justice Douglas dismissed Justice Frankfurter's four guidelines for construing the statute ${ }^{113}$ as irrelevant to the first amendment issues involved, ${ }^{114}$ and he found the Act too broadly drawn to serve solely the purpose of protecting minority interests. ${ }^{115} \mathrm{He}$ suggested that the protection of minority interests might instead be accomplished by following the British practice of allowing dissenters to refuse to contribute for political purposes. ${ }^{116}$

Legal commentators have attacked the restrictions on political contributions and expenditures along other lines. One thoughtful analysis suggests that there is a distinction, unrecognized by the courts or by Congress, between the electoral and political processes:

The electoral process may be defined as the necessary elements to a full exercise of the democratic franchise. It would include, therefore, the processes of making a choice

109 Id. 146 (Rutledge, J., concurring). Because Justice Rutledge acknowledged that Congress could regulate political contributions and expenditures by appropriate measures not trenching on first amendment rights, $i d .139$, his objections must be viewed in light of the totality of the ban on union contributions and expenditures in federal elections. At the time CIO was decided, the statute did not specifically exclude from the definition of expenditures funds to establish and administer a separate political fund financed by voluntary contributions.

$110 \mathrm{Id}$. 144 (Rutledge, J., concurring).

111352 U.S. 567, 598 (1957) (Douglas, J., dissenting).

112 Id. 598 n.2 (Douglas, J., dissenting).

113 Text accompanying note 57 supra.

114352 U.S. at 595-96 (Douglas, J., dissenting).

115 Id. 597 (Douglas, J., dissenting).

110 Id. 597 n.I (Douglas, J., dissenting). 
or selecting a representative, the procedures of candidate selection (ballot access, nomination, primary elections, conventions, and caucuses), and the mechanics of casting ballots (forms, time, and place). . . .

The political process, on the other hand, may be defined as the broad concept of advocacy. It includes the advocacy of ideas and the free and open discussion of beliefs. In short, the political process is the formulation by the people of governmental policy, whereas the electoral process is the formation of governmental administration. ${ }^{117}$

Under this analysis, the electoral process, because it is unrelated to the content of political expression, would be open to regulation, subject to the equal protection clause, while "the political freedoms [would be] free from all governmental regulation, whether equally applied or not, that directly suppresses free expression or regulates its content." 118

Another line of analysis adopts a less absolutist approach but arrives at the same conclusion of unconstitutionality. According to this view, the legislative purpose of combatting aggregated wealth is negated because the statutory provisions permit unlimited campaigning financed by the general treasury as long as it is aimed at members and permit unlimited campaigning aimed at the general public so long as it is financed by voluntary contributions. Therefore, one commentator found the sole remaining purpose of the statute to be the protection of dissenters who may not wish to contribute to a particular candidate or cause. ${ }^{119}$ Because the "true dissenters" whom the statute was intended to protect may in fact be few, and because less restrictive means of protecting minority interests exist, this view favors a finding of unconstitutionality.

\section{B. Buckley v. Valeo}

Although Buckley v. Valeo did not directly address the ban on union political activity then contained in section 610 of title 18, the opinion cast some light on the constitutional considerations surrounding that section. Perhaps the most significant aspect of the

117 Comment, Campaign Finance Acts-An Attempted Balance Between Public Interests and Individual Freedoms, 24 U. KAN. L. REv. 345, 347 (1976) (footnotes omitted).

118 Id. 350 (footnote omitted).

119 Comment, The Constitutionality of the Federal Ban on Corporate and Union Campaign Contributions and Expenditures, 42 U. Ckr. L. REv. 148, 151-52 (1974). The Supreme Court rejected this analysis in Cort v. Ash, 422 U.S. 66, 81-82 \& n.I3 (1975). 
Court's opinion was its acknowledgement of the validity of the governmental purpose underlying the regulation of federal election campaigns: "It is unnecessary to look beyond the Act's primary purpose-to limit the actuality and appearance of corruption resulting from large individual financial contributions-in order to find a constitutionally sufficient justification for the $\$ 1,000$ contribution limitation." 120

The Court realized that the 1974 Amendments to FECA did to some degree curtail first amendment rights, but it drew a distinction between limitations on contributions, which were held to be constitutional, and limitations on expenditures, which were held to be unconstitutional. The basis for the distinction lay in the Court's understanding of the different purposes of contributions and expenditures:

[A] contribution serves as a general expression of support for the candidate and his views, but does not communicate the underlying basis for support. The quantity of communication by the contributor does not increase perceptibly with the size of his contribution, since the expression rests solely on the undifferentiated, symbolic act of contributing. At most, the size of the contribution provides a very rough index of the intensity of the contributor's support for the candidate. . . . ${ }^{121}$

The restriction of expenditures, however, "necessarily reduces the quantity of expression by restricting the number of issues discussed, the depth of their exploration, and the size of the audience reached." ${ }^{122}$ The Court was unconvinced by the argument on the one hand that limitations on individual contributions would decrease the total quantity of political expression. ${ }^{123}$ On the other hand, the Court was similarly unconvinced that the possibility of individuals expending large sums of money in order to solicit political favors after the election justified the imposition of a ceiling on independent expenditures. ${ }^{124}$

The Buckley opinion, by analogy, reflects on the constitutionality of section 112 of the 1976 Amendments. The purpose of preventing corruption or the appearance of corruption was accorded

120424 U.S. at 26.

121 Id. 21.

122 Id. 19.

123 Id. 21.

124 Id. 45. 
recognition by the Court as a legitimate government interest. ${ }^{125}$ : The opinion rejects the absolutist concept that any regulation of political activity is forbidden by the first amendment. Rather, the specific pitfall that the statute must avoid is "substantial and direct" restrictions on ... protected political expression." ${ }^{26}$ Buckley $\nu_{\text {. }}$ Valeo, however, yields no easy answer to the question of what constitutes protected political expression.

\section{The Application of Buckley v. Valeo to Section 112}

Buckley contains language that supports the opposing views on. the constitutionality of section 112. Supporting the view that the statute is unconstitutional is the Court's rejection of the idea that "government may restrict the speech of some elements' of 'our' society in order to enhance the relative voice of others . . . "127 The Court found such an idea alien to the first amendment, which was intended to foster " "the widest possible dissemination of information" " and " 'to assure unfettered interchange of ideas for the bringing about of political and social changes desired-by the people." "128 The Court asserted that the protection of the first amendment could not depend on the degree to which an individual's wealth enables him to engage in public discussion. ${ }^{129}$

It may be argued, however, that corporations and labor unions should be held to different and more stringent standards than an individual or other associations under a regulatory scheme for campaign financing. The Buckley opinion revealed that the Court would. consider practical considerations in reaching a constitutional balance. For example, in discussing the limitations on contributions, the Court reasoned that FEGA's ceilings on contributions would merely require a candidate to solicit funds from a greater number of sources rather than reduce the total amount of money available: for financing campaigns. ${ }^{130}$

A similar factual analysis in the case of unions and corporations could lead the Court to conclude that a greater danger of corruption or the appearance of corruption exists in the case of unions

125 Id. 25-26.

126 Id. 58-59.

127 Id. 48-49.

${ }^{128}$ Id. 49, quoting New York Times Co. v. Sullivan, 376 U.S. 254, 266, 269 (1964) (quoting Associated Press v. United States, 326 U.S. 1, 20 (1945) and Roth v. United States, 354 U.S. 476, 484 (1957)).

129 Id.

$130 \mathrm{Id}$. 2I-22. 
and corporations ${ }^{131}$ or that, due to the provision permitting separate political funds, the present statutory system simply does not affect the amount of money available for political communication. Furthermore, the Court indicated in Buckley that it was not applying a severe least restrictive alternative analysis. The Court held that although such less restrictive measures as bribery laws and narrowly drawn disclosure statutes could conceivably dispel the appearance of corruption, Congress might reasonably conclude that such measures were only a partial solution and that a broader statutory scheme was needed to deal with the reality of political campaigns. ${ }^{132}$

In view of the Court's willingness to defer to Congress in this area, the differences between individuals and unions might lead the Court to uphold the constitutionality of the scheme regulating a union's political activity. First, the ban on union political contributions and expenditures is not total but applies only to general union funds. Contributions and expenditures made by a separate fund financed by voluntary contributions are specifically permitted, as are expenditures of general funds to solicit contributions to the separate fund. In order to engage in political discussion, a union need only convince its members that its views are sound enough to merit a contribution to a union political committee espousing the same political philosophy. The necessity of convincing union members of the value of such a contribution does not amount to a constitutionally invalid burden. After all, if union members are so unconvinced of the reasonableness of the union's position that they refuse to support it, the argument for prohibiting the union from spending dues money to support its political views is greatly strengthened. In the case of individual political contributions, there is only voluntary action on behalf of a candidate; no coercive element that would raise first amendment questions exists. In the case of unions, the statute strikes a legitimate and reasonable accommodation by distinguishing between the uses to which a separate, voluntary fund and the general treasury fund may be put.

A second consideration arguing in favor of the statute's constitutionality is the fact that the size of voluntary political funds maintained by unions in recent years suggests that members do support their union's endeavors in the political arena. Labor has

131 For example, the Court in Buckley gave some weight to "pernicious practices," $i d$. 27, that surfaced in the 1972 presidential election. With respect to questionable, if not illegal, contribution procedures used by many corporations, see generally G. Thayer, Who Shakes the Monex Tree? 108-22 (1973).

132424 U.S. at 27-28. 
emerged as the single most important broad interest group in the funding of congressional campaigns. ${ }^{133}$ As a result, it is difficult to argue that the statute has caused a diminution in the "number of issues discussed, the depth of their exploration, and the size of the audience reached." 134

Buckley thus provides contradictory guidance on the constitutionality of section 112. The language striking down the expenditure limitations of the FECA Amendments of 1974 could be applied equally to the expenditure ban placed on general union funds. When viewed as a whole, however, the regulatory scheme is narrowly.and reasonably drawn to obviate the evil to which Congress addressed itself: the use of general union funds for active electioneering aimed at the general public in connection with an election for federal office. At the same time, the statute does not prevent unions from "effectively amplifying the voice of their adherents, the original basis for the recognition of First Amendment protection of the freedom of association." ${ }^{135}$

\section{The Dilemma of Dissidents}

\section{A. The Problem of Intra-Union Expenditures}

Despite the explicit statutory provision that permits a union to expend a separate, voluntary fund for political purposes, section 112 of the 1976 Amendments to FECA still raises several problems for union members who disagree with the political choices of the union. ${ }^{136}$ A union may expend funds raised by regular dues for campaigning aimed at union members and their families; dues monies may also be used to establish and administer a separate, voluntary political fund. ${ }^{137}$ If, as can be expected, the union hierarchy also heads the separate fund, the political direction of the fund will most likely mirror that of the union itself. Consequently, although the dissenter may not contribute to the separate fund, his dues monies may ultimately further the same purposes to which he objects. ${ }^{138}$

133 Text accompanying notes 16-17 supra.

134 Buckley v. Valeo, 424 U.S. 1, 19 (1976) (footnote omitted).

135 Id. 22.

136 See Note, Corporate Democracy and the Corporate Political Contribution, 61 IOWA L. REv. 545, 579 (1975).

137 See text accompanying notes 83-89 supra.

138 To the extent that the dissenter's funds help to defray the costs of administering the separate fund, he frees other funds that may be expended for active electioneering. 
In addition, doubt has been expressed concerning the protection provided by the voluntariness requirement established in Pipefitters and the statute itself. ${ }^{139}$ Justice Powell, dissenting in Pipefitters, worried that "[ $\mathrm{t}]$ he trappings of voluntariness might be achieved while the substance of coercion remained." 140 Herbert Alexander, an observer of American campaign finance, has noted: "[T]here are subtle kinds of coercion. If a shop steward in the union asks a rank and file member to make a contribution to [a political action committee], there's a subtle kind of pressure because he wants to curry the favor of the shop steward." 141 The provisions of the FECA Amendments of 1976, requiring that potential contributors be advised of the purpose of the fund and of their right to refrain from contributing, ${ }^{142}$ are positive steps in this regard, but in a pervasively coercive atmosphere, their protection may be scant indeed.

Nevertheless, unions are majoritarian institutions, and as such offer channels for redirecting policy and structure. Union officials are elected democratically, either by the direct vote of the members or by the vote of democratically elected delegates. ${ }^{143}$ These officials normally set the political tone of the union and its committees, although some unions may choose their political endorsements by a democratic convention system. ${ }^{144}$ One course open to dissidents, therefore, is to challenge the politics of their leaders within the structure of the union, because "the free speech rights of rank and file members . . . include by definition a right of democratic insurgency, both at common law and under modern statutory standards." 145 Union members have indicated that they are not reticent to oppose the political course they perceive their national officials to be following. ${ }^{146}$

139 Federal Election Campaign Act Amendments of 1976, Pub. L. No. 94-283, $\$ 112,90$ Stat. 475,491 (to be codified in 2 U.S.C. $\$ 441 \mathrm{~b}$ ).

140407 U.S. at 449 (Powell, J., dissenting).

141 Symposium on Campaign Financing Regulation Sponsored By ABA Spectal Comamtiee on Election Reform 66 (1975) (comments of Herbert Alexander). The opposing view has been expressed that the shop steward must in fact curry the favor of the rank and file. Id. (comments of Steven Scholsberg).

142 See text accompanying note 92 supra.

143 Labor Management Reporting and Disclosure Act of 1959, $\$ 401$ (a), 29 U.S.C. $\$ 481(\mathrm{a})(1970)$.

144 Symposiun, supra note 141, at 66 (comments of Steven Scholsberg).

145 Cloke, Labor Democracy, Free Speech and the Right of Rank and File Insurgency, 4 U. SAN FERN. V. L. REv. 1, 1-2 (1975).

146 See, e.g., McNamara v. Johnston, 522 F.2d 1157 (7th Cir. 1975), cert. denied, 425 U.S. 911 (1976); Colorado Labor Council v. AFL-CIO, 349 F. Supp. 37 (D. Colo. 1972), vacated, 481 F.2d 396 (10th Cir. 1973). 
Needless to say, an entrenched majority can be expected to combat the efforts of a vocal minority, but should the majority overstep its bounds and combat the dissidents with economic retaliation, such as revocation of union rights and privileges, individual union members could seek relief under the rights guaranteed by Title I of the Labor Management Reporting and Disclosure Act (LMRDA). ${ }^{147}$ Aside from his LMRDA rights, a dissenter who is discriminated against in the bargaining process or the administration of the collective agreement as a result of his political views could seek redress in a suit for the violation of the duty of fair representation..$^{148}$

\section{B. Street and Related Cases}

If the majority victoriously combats speech with speech and does not alter its political stance, the dissident may still object to the expenditure of his dues for political purposes. The Supreme Court was confronted with such a problem in three cases that arose under the Railway Labor Act. ${ }^{149}$ Section 2, Eleventh of the Act specifically permits unions and employers to enter into union security agreements by collective bargaining. ${ }^{150}$ Such agreements could eventually force all employees to become dues-paying members of the union if they wish to retain their jobs. Unlike the National Labor Relations Act, the Railway Labor Act contains no provision allowing states to nullify the union security provision of the Act. ${ }^{151}$

In Railway Employes' Department v. Hanson ${ }^{152}$ a group of railway employees sought to enjoin the enforcement of such a union security clause on the ground that the agreement infringed their first amendment rights. The trial court granted the injunction, and the Nebraska Supreme Court affirmed. The record in Hanson,

14729 U.S.C. $\$ \$ 411-15$ (1970). See Mitchell v. International Ass'n of Machinists, 196 Cal. App. 2d 796, 16 Cal. Rptr. 855 (Ct. App.), cert. denied, 370 U.S. 974 (1961) (union member could not be subjected to union discipline for his political support of a "right-to-work" law, when such activity was not patently in conflict with the best interest of the union). Contra, DeMille v. American Fed'n of Radio Artists, 31 Cal. 2d 139, 187 P.2d 769, cert. denied, 333 U.S. 876 (1948) (union member could be subjected to union discipline for failure to pay assessment to oppose proposition allowing "right-to-work" law).

148 See Vaca v. Sipes, 386 U.S. 171 (1967); Steele v. Louisville \& N.R. Co., 323 U.S. 192 (1944).

14845 U.S.C. $\$ 152$ (1970).

15045 U.S.C. § 152, Eleventh (1970).

151 Compare id. with 29 U.S.C. $\$ 164(\mathrm{~b})$ (1970).

152351 U.S. 225 (1956). 
however, was devoid of evidence of attempts to force ideological conformity. The Supreme Court therefore reversed:

It is argued that compulsory membership will be used to impair freedom of expression. But that problem is not presented by this record. . . . [I]f the exaction of dues, initiation fees, or assessments is used as a cover for forcing ideological conformity or other action in contravention of the First Amendment, this judgment will not prejudice the decision in that case. For we pass narrowly on $\$ 2$, Eleventh of the Railway Labor Act. We only hold that the requirement for financial support of the collectivebargaining agency by all who receive the benefits of its work is within the power of Congress under the Commerce Clause and does not violate either the First or the Fifth Amendments. ${ }^{153}$

In International Association of Machinists $v$. Street ${ }^{154}$ another group of railroad employees similarly sought to enjoin a union shop agreement. In Street, however, the employees alleged, ${ }^{155}$ and the trial court found, ${ }^{156}$ that "the money each was thus compelled to pay to hold his job was in substantial part used to finance the campaigns of candidates for federal and state offices whom he opposed, and to promote the propagation of political and economic doctrines, concepts and ideologies with which he disagreed." 157 It was not alleged, however, that the expenditures violated the Federal Corrupt Practices Act or any state corrupt practices legislation..$^{158}$ The Georgia courts found that the union's use of the mandatory dues for political purposes violated the dissenters' first and fifth amendment rights. ${ }^{159}$

The United States Supreme Court reversed the decision of the Georgia court, finding that the union shop agreement itself was not unlawful. ${ }^{160}$ But the Court did not rule on the constitutionality of the nonconsensual use of dues money for political purposes, although the Court admitted that the record squarely presented constitutional issues. ${ }^{161}$ Rather, the Court held that the

153 Id. 238.

154367 U.S. 740 (1961).

155 Id. 744.

156 Id. 744 \& n.2.

157 Id. 744.

158 Id. 773 n.21.

159 Id. 744-46 \& nn.3 \& 4.

160 Id. 771 .

161 Id. 749. 
Railway Labor Act itself does not permit a union to use a dissenter's dues against his wishes for political purposes. ${ }^{162}$ The Street Court asserted that a dissenter must first make his objections known to the union, and then proposed two remedies to be considered on remand:

One remedy would be an injunction against expenditure for political causes opposed by each complaining employee of a sum, from those moneys to be spent by the union for political purposes, which is so much of the moneys exacted from him as is the proportion of the union's total expenditures made for such political activities to the union's total budget. The union should not be in a position to make up such sum from money paid by a nondissenter, for this would shift a disproportionate share of the costs of collective bargaining to the dissenter and have the same effect of applying his money to support such political activities. A second remedy would be restitution to each individual employee of that portion of his money which the union expended, despite his notification, for the political causes to which he had advised the union he was opposed. ${ }^{163}$

In Brotherhood of Railway or Steamship Clerks $v$. Allen ${ }^{164}$ the Court clarified the conditions under which an employee may petition for the Street remedies. Specifically, the Court held that an employee's opposition to political expenditures may be expressed in a general, all-encompassing way, rather than by enumerating each particular cause he opposed..$^{165}$

The Court's opinions in these three cases were based on statutory grounds, as in the Federal Corrupt Practices Act cases. Consequently, the question whether a union in a union shop situation could use dues monies for political purposes to which the duespayer has objected without violating the dissenter's first amendment rights was left unanswered. That issue, however, was squarely presented and decided in Abood $v$. Detroit Board of Education. ${ }^{166}$

\section{Abood: The Constitutional Issue Confronted}

Abood arose under a Michigan statute that permitted a union and a local government employer to enter into an agency shop

162 Id. 765-70.

163 Id. 774-75.

164373 U.S. 113 (1963).

$165 \mathrm{Id}$. 118. For an elaboration of this holding of Allen, see Abood v. Detroit Bd. of Educ., 97 S. Ct. 1782 (1977).

16697 S. Ct. 1782 (1977). 
agreement "whereby every employee represented by a union-even though not a union member-must pay to the union, as a condition of employment, a service fee equal in amount to union dues." 167 Drawing upon the reasoning of Hanson and Street, the Supreme Court upheld the agency shop principle. Unlike the Railway Labor Act cases, however, the Court was unable to dispose of the constitutional question by declaring that the use of a dissenting member's dues monies for political purposes was prohibited by the statute because the Michigan Court of Appeals had ruled that the Michigan statute permitted such a use. ${ }^{168}$ Squarely faced with the issue that was avoided in the Railway Labor Act cases, the Abood Court held that compelled contributions by dissenters violated the dissenters' first amendment rights: ${ }^{169}$ "The fact that [the employees] are compelled to make, rather than prohibited from making, contributions for political purposes works no less an infringement of their constitutional rights." 170

The first amendment, of course, provides protection only against actions of the state. The requisite state action was found in Abood because local governments, as employers, entered into the disputed agency shop agreements under a statutory authorization.

In Hanson and Street, the Railway Labor Act, which authorized the union shop agreement, provided an adequate nexus to state action. As the Court pointed out in $A b o o d$, "[t] he plaintiffs' claims in Hanson failed, not because there was no governmental action, but because there was no First Amendment violation." 171 Neither Abood nor Hanson and Street provide direct guidance, however, to cases of a union shop agreement under the National Labor Relations Act (NLRA). ${ }^{172}$

167 Id. 1787.

168 Id. 1798.

169 Id. 1798-1800. holding:

$170 \mathrm{Id}$. 1799. The Abood Court went on to make explicit what it was not

We do not hold that a union cannot constitutionally spend funds for the expression of political views, on behalf of political candidates, or towards the advancement of other ideological causes not germane to its duties as collective bargaining representative. Rather, the Constitution requires only that such expenditures be financed from charges, dues, or assessments paid by employees who do not object to advancing those ideas and who are not coerced into doing so against their will by the threat of loss of governmental employment.

Id. 1800.

171 Id. 1795.

17229 U.S.C. $\$ 158(\mathrm{a})(3)(1970)$. 
The state action question under the NLRA need not be reached if the statute is authoritatively construed to prohibit the nonconsensual use of dues for political purposes, as the Court construed the Railway Labor Act in Street. Although the Supreme Court has never given the Act such a construction, some unions have tacitly acknowledged that such a construction is applicable. ${ }^{173}$ As a result, many unions have voluntarily allowed members to contract out of any political activities. ${ }^{174}$ If the Act were not construed to forbid compulsory political contributions, it would then be necessary to determine if sufficient state action were present to activate an $A b o o d$-type constitutional analysis.

\section{Union Activity as State Action}

Unlike the Railway Labor Act, section $14(\mathrm{~b})$ of the NLRA does allow states to prohibit union shop agreements. This distinction alone led the Tenth Circuit to conclude that the use of nonunion employees' dues in an agency shop situation for political purposes would raise no first amendment problems, as the state's position in this case is "neutral and permissive." 175 This neutral stance presumably stems from the fact that the NLRA permits the states to forbid union security agreements. The First ${ }^{176}$ and Ninth ${ }^{177}$ Circuits have disagreed, refusing to distinguish between the Railway Labor Act and the NLRA. In Linscott v. Millers Falls Co., ${ }^{178}$ the First Circuit reasoned that "[i]f federal support attaches to the union shop if and when two parties agree to it, it is the same support, once it attaches, even though the consent of a third party, the state, is a precondition." ${ }^{179}$ The court thus found the same degree of government involvement under the NLRA to justify a finding of state action, regardless of the fact that a state could revoke union security agreements. In fact, the First Circuit may have underestimated the degree of federal involvement. The NLRA does not require the consent of the state but rather permits the state to outlaw union shops. From a political and practical view-

173 See, e.g., Reid v. UAW, 479 F.2d 517, 518 (10th Cir.), cert. denied, 414 U.S. 1076 (1973).

174 See, e.g., Seay v. McDonnell Douglas Corp., 371 F. Supp. 754, 758-59

(C.D. Cal. 1973), aff'd in part and rev'd in part, 533 F.2d 1126 (9th Cir. 1976). 175 Reid v. McDonnell Douglas Corp., 443 F.2d 408, 410 (10th Cir. 1971).

176 See Linscott v. Millers Falls Co., 440 F.2d 14 (1st Cir.), cert. denied, 404 U.S. 872 (1971).

177 See Seay v. McDonnell Douglas Corp., 427 F.2d 996 (9th Cir. 1970).

178440 F.2d 14 (1st Cir.), cert. denied, 404 U.S. 872 (1971).

179 Id. 16. 
point, mustering the support to pass a "right-to-work" law is more difficult than preventing the passage of a bill permitting union security agreements. Inactivity is often the more politically expedient route; in this instance that inertia favors the proponents of union security agreements.

In Abood the Supreme Court cited language from the Hanson opinion that supported a finding of government action: "[T]he federal statute is the source of the power and authority by which any private rights are lost or sacrificed. . . . The enactment of the federal statute authorizing union shop agreements is the governmental action on which the Constitution operates. . .."180 Therefore, if faced with a first amendment claim by a dissenting union member under the NLRA, the Court would be confronted with two alternatives: 1) the use of such dues might be held to violate the dissenter's first amendment rights; or 2) as in the case of the Railway Labor Act, the NLRA might be interpreted to prohibit such a use, thereby making the application of Street remedies appropriate.

\section{E. The Application of Street Remedies to the NLRA}

The NLRA declares it to be national policy to encourage "the practice and procedure of collective bargaining." 181 To facilitate collective bargaining, a union selected by a majority of the employees in an appropriate bargaining unit is designated as the exclusive bargaining representative for all employees in that unit, whether or not they belong to the union.182 Except where specifically prohibited by state law, the collective agreements entered into by the employer and the exclusive representatives may include union security clauses similar to the one in Street. Five different factual situations that arise under the NLRA present the question whether the Street remedies should be available to a given dissenter:

1) In the event the union does not represent the majority of employees and therefore is not the exclusive bargaining agent, the individual employee may nonetheless voluntarily join the union;

2) In the event the union does not represent the majority of employees and therefore is not the exclusive bargaining agent,

18097 S. Ct. at 1791 n.12.

18129 U.S.C. $\$ 151$ (1970).

18229 U.S.C. $\$ 159$ (a) (1970). 
the individual employee may decline to join the union without risking his job security;

3) If the union is chosen by a majority of the employees as their bargaining agent and if no union security agreement is reached, the employee may decline to join the union, but it will still be his bargaining representative;

4) If the union is chosen by a majority of the employees as their bargaining agent and if no union security agreement is reached, the employee may voluntarily join the union;

5) If the union is chosen by a majority of the employees as their bargaining agent and if a union security agreement is signed by the employer and the union, the employee will be required to become a union member within thirty days of employment, subject to the proviso of section $8(a)(3)$ of the NLRA. ${ }^{183}$

If the individual is not a union member, or is not required to pay dues under a union security agreement (cases 2 and 3), the issue of the union's use of his dues monies for political purposes cannot arise; therefore, no analysis of the applicability of the Street remedies is required. In the other cases, an analysis of the unionemployee relationship is necessary.

In the case of an employee who voluntarily joins a union that is not the exclusive bargaining representative for collective bargaining purposes (case 1), the arguments for making the Street remedies available are the least persuasive. The employee's membership in the union is not compelled by a union security agreement authorized by statute, nor must the employee rely on this union to bargain for him, a situation that might induce him to join the union even if not required by a union security agreement. Although the minority union may bargain for him if there is no majority bargaining representative, the employee is free to bargain for himself or to support the efforts of another union in its effort to gain

18329 U.S.C. $\S 158(\mathrm{a})(3)$ (1970). The proviso states:

That no employer shall justify any discrimination against an employee for nonmembership in a labor organization (A) if he has reasonable grounds for believing that such membership was not available to the employee on the same terms and conditions generally applicable to other members, or (B) if he has reasonable grounds for believing that membership was denied or terminated for reasons other than the failure of the employee to tender the periodic dues and the initiation fees uniformly required as a condition of acquiring or retaining membership. 
majority status. His membership is neither required by a union security agreement nor economically compelled by the union's status as exclusive bargaining representative. If he disagrees with the political causes supported by the union with his dues, the employee may terminate his union membership without fear of losing his job or forfeiting all input into his bargaining relationship with the employer. Although the employee may not desire to sever his relationship with the union to this degree, but may prefer to remain a member while retaining the Street remedies for political expenditures to which he objects, his dues cannot be considered "exacted funds" as were the dues collected under the union security agreement in Street. 184

In the case of an employee who is bound by a union security agreement (case 5), an exact parallel of the Street case is presented. The same considerations support a finding that the NLRA does not authorize the nonconsensual use of exacted dues for political purposes. Because the employee is compelled to join the union under a statutorily sanctioned union security agreement, the question whether the employee would have joined the union voluntarily absent the union security clause is extraneous to the analysis. The crux of the issue is that the employee must maintain his dues-paying membership under the agreement to avoid the risk of losing his job. Unlike the employee in case 1, he may not resign from the union in protest of the union's political activities without risking serious repercussions.

The most difficult case is presented by an employee who belongs to a majority union that is not covered by union security clause (case 4). Unlike his counterpart in case 5 , he is free to quit the union without risking the loss of his job. Unlike case 1, however, the union continues to be his bargaining representative even if he leaves the union in protest. Although the exclusive bargaining agent owes a duty of fair representation to all whom it represents and not just to its members, ${ }^{185}$ the employee may feel that to be forced to quit his union in order to forestall the expenditure of his dues monies for political purposes that he opposes is an unacceptable alternative. By resigning from the union he loses his rights as a union member. ${ }^{186}$ By foregoing those rights, which include discussion of union business and nomination and election of union

184 International Ass'n of Machinists v. Street, 367 U.S. 740, 768-69 (1961).

185 Steele v. Louisville \& N.R. Co., 323 U.S. 192 (1944).

18629 U.S.C. $\$ \$ 411-15$ (1970). 
officers, ${ }^{187}$ he may lose his ability to affect the formation of the collective agreement that structures the legally binding terms and conditions of his employment. ${ }^{188}$ A union member faced with such a Hobson's choice might well argue that the NLRA incorporates Street-type remedies. The fact that a statute establishes a majority union as the exclusive bargaining representative led to the formulation of a duty of fair representation. ${ }^{189}$ Analogous considerations would justify the application of Street remedies in this case, primarily because the Street remedies permit the employee to exercise his first amendment rights without foregoing his rights within the union structure. ${ }^{190}$

However well the Street remedies may protect dissenting union members when unions act within the bounds of the law, different considerations come into play when there is a statutory violation. The final section of this Comment will consider the remedies available to protect the interests of union dissidents and the general public should a union or its officials violate the current statutory prohibitions. Due to the similar statutory treatment afforded unions and corporations, cases involving corporate stockholders will also be considered.

\section{REMEdies For Statutory VIOLATIONS BY UNIONS}

The clearest remedy for violations of the statutory prohibition against the use of a union's general treasury funds for electioneering aimed at the public is a criminal prosecution. The Department of Justice is empowered to press charges when an individual or an organization violates the Federal Election Campaign Act. ${ }^{191}$ In United States $v$. Boyle, ${ }^{192}$ such charges were successfully brought under section 610 of title 18 against W. A. Boyle, former president of the United Mine Workers. The Circuit Court of Appeals for the District of Columbia asserted that in order for the government to prevail under section 610 , it must establish that "(1) a labor organization (2) made a contribution or expenditure (3) in con-

187 Id. $\$ 411(\mathrm{a})(1) \&(2)$.

188 See 29 U.S.C. $\$ 151$ (1970).

189 Steele v. Louisville \& N.R. Co., 323 U.S. 192 (1944).

190 Cf. Comment, Employee Challenges to Arbitral Awards: A Model for Protecting Individual Rights Under the Collective Bargaining Agreement, $125 \mathrm{U}$. PA. L. REv. 1310 (1977) (a union member should not be compelled to sue his own union in a duty of fair representation suit in order to vindicate his rights under the contract).

191 Federal Election Campaign Act Amendments of 1976, Pub. L. No. 94-283, $\$ 109,90$ Stat. $475,485-86$ (to be codified in 2 U.S.C. $\$ 437 \mathrm{~g}$ ).

192482 F.2d 755 (D.C. Cir.), cert. denied, 414 U.S. 1076 (1973). 
nection with a specified federal election (4) for purposes of active electioneering and that (5) the defendant officer consented to the making of the contribution." 193 In addition to the criminal provisions of FECA, the Federal Election Commission is charged with civil enforcement of the statute. The Commission may seek injunctive relief against any ongoing violations. ${ }^{194}$ Furthermore, the Commission may refer a case to the Department of Justice for investigation and possible prosecution. ${ }^{195}$

More difficult questions arise when individual union members or stockholders seek redress for statutory violations. Injunctive relief is beyond the reach of individuals because the responsibility for seeking this remedy is explicitly vested in the Federal Election Commission. ${ }^{196}$ On the federal level, individual union members and shareholders in corporations have attempted to prosecute civil suits based on section $610^{197}$ and the duty of fiduciary responsibility. ${ }^{198}$ The major case in this area is Cort $v$. Ash. ${ }^{199}$ In Cort a shareholder of Bethlehem Steel, a Delaware corporation, asserted an implied private cause of action against the corporation and its directors for an alleged violation of section 610 . The Supreme Court, reversing the Third Circuit, found that the "implication

$193 \mathrm{Id}$. 760. In addition to the conviction under $\$ 610$, Boyle was convicted of violating the statutory duty of fiduciary responsibility. Id. 764-66. The duty of fiduciary responsibility requires union officials "to hold [the union's] money and property solely for the benefit of the organization and its members and to manage, invest, and expend the same in accordance with its constitution and bylaws and any resolutions of the governing bodies adopted thereunder." 29 U.S.C. \$501(a) (1970). If expenditures are authorized by the union in accordance with its constitution, that constitutes a defense to the charge of violating fiduciary responsibility, but it is not a defense to a charge of violating the Federal Election Campaign Act. McNamara v. Johnston, 522 F.2d 1157, 1165 \& n.10 (7th Cir. 1975), cert. denied, 425 U.S. 911 (1976).

194 Federal Election Campaign Act Amendments of 1976, Pub. L. No. 94-283, $\$ 109,90$ Stat. $475,483-86$ (to be codified in 2 U.S.C. $\$ 437 \mathrm{~g}$ ).

$195 \mathrm{Id}$.

196 See Cort v. Ash, 422 U.S. 66 (1975); McNamara v. Johnston, 522 F.2d 1157, 1162 (7th Cir. 1975), cert. denied, 425 U.S. 911 (1976). Dissident union members have, however, successfully sought declaratory judgments invalidating dues allocations to political funds when the expenditure of those funds would have violated the statute. See Barber v. Gibbons, 367 F. Supp. 1102 (E.D. Mo. 1973). 197 Cort v. Ash, 422 U.S. 66 (1975).

198 McNamara v. Johnston, 522 F.2d 1157 (7th Cir. 1975), cert. denied, 425 U.S. 911 (1976). Further possibilities include derivative suits or individual suits for damages under state law. In a discussion of state and common law remedies in the case of a shareholder of a corporation, it has been suggested that "[ $t] 0$ prevail in an action for damages against a corporate official who approved a political expenditure, the shareholder must prove that the official's conduct either constituted ultra vires activity or was in breach of his or her fiduciary duty." Note, Corporate Democracy and the Corporate Political Contribution, 61 IowA L. REv. 545, 566 (1975).

199422 U.S. 66 (1975). 
of such a federal cause of action is not suggested by the legislative context of $\S 610$ or required to accomplish Congress' purposes in enacting the statute." 200 The Court's decision hinged in part on its assertion that Congress was primarily concerned with the effect of aggregate corporate wealth on federal elections rather than with the internal relations between a corporation and its stockholders. ${ }^{201}$ The Court added a twist to Cort by suggesting that the factors militating against the implication of a private cause of action in the case of a corporate shareholder might not be present in the case of a dissident union member who institutes a civil damage action against the union based on a statutory violation. The Court based this dictum on its conclusion that thęre existed a great degree of concern for the protection of union members when labor unions were included within the coverage of section 610. The Court reasoned:

This difference in emphasis may reflect a recognition that, while a stockholder acquires his stock voluntarily and is free to dispose of it, union membership and the payment of union dues is often involuntary because of union security and checkoff provisions. ... I It is therefore arguable that the federal interest in the relationship between members and their unions is much greater than the parallel interest in the relationship between stockholders and state-created corporations. In fact, the permanent expansion of $\S 610$ to include labor unions was part of comprehensive labor legislation, the Taft-Hartley Act of 1947, while the 1907 Act dealt with corporations only with regard to their impact on federal elections. ${ }^{202}$

The implication of a private right of action from a statute that does not expressly authorize such a right depends partly on the extent to which the existing enforcement mechanism is inadequate to serve the purposes of the statute..$^{203}$ The Court's logic with respect to the dictum on implying a private cause of action against unions is therefore flawed on two grounds. First, if the primary purpose of FECA is indeed to counteract the effect of aggregate wealth, as was asserted in Cort, rather than to regulate the internal affairs of corporations, the implication of a private right of action

200 Id. 69.

201 Id. 81-82.

202 Id. 81 n.13.

203 Comment, Private Rights of Action Under Amtrak and Ash: Some Implications for Implication, 123 U. PA. L. REv. 1392, 1393 (1975). 
against a union is similarly unwarranted. The Court acknowledged in Cort $v$. Ash that the congressional concern with counteracting the effects of aggregate wealth did not justify the implication of a private right of action because the enforcement mechanism established by FECA was sufficient. ${ }^{204}$ This reasoning applies equally to unions, which are subject to the same criminal and civil penalties as corporations under FECA. ${ }^{205}$ Second, even if the federal interest in regulating the internal affairs of unions is stronger under FECA for the reasons mentioned in Cort, the remedies suggested in this Comment would adequately protect the interests of individual union members, who might otherwise have no recourse besides a civil damage suit to remedy the use of union funds in a manner that violates both the statute and their rights within the union. ${ }^{206}$

\section{Conclusion}

Although the federal courts have considered the legislative scheme regulating the political activities of labor unions for nearly thirty years, the Supreme Court has steadfastly declined to rule on its constitutionality. Congress, however, has refined its legislation in this area, partly in response to guidance from the Court's opinions. Consequently, the present regulatory system contains a general prohibition of contributions or expenditures aimed at the general public in connection with a federal election financed by general union funds, while specifically permitting expenditures and regulated contributions from separate voluntary funds. This system fulfills the twin legislative goals in this area of abating the dangers of aggregated wealth and protecting dissident union members. The present system thereby reflects a balance between the legitimate state interest of preventing corruption, or the appearance of corruption, in the political system, and the rights of association and freedom of expression of union members. The present system therefore passes constitutional muster because it reasonably distinguishes between

204422 U.S. at 84.

205 If an implied cause of action can be viewed as a deterrent to statutory violations, the greatest need for a deterrent may in fact exist in the case of corporations, not unions, notwithstanding Cort's language concerning the stronger federal interest in unions. First, the resources available to corporations which could potentially be used to contravene the statute are vastly superior to those of unions. See A. HEARD, supra note 11, at 171 \& n.8. Second, despite the claim of shareholder control, unions are more democratic institutions because unions operate on a one-man-one-vote principle, while corporations operate on a one-share-one-vote principle, which makes them susceptible to control by a small group of individuals. See A. Rosentrat, supra note 25, at 29-30; Rauh, Legality of Union Political Expenditures, 34 S. CaL. L. REv, 152, 162 n.49 (1961).

206 See text accompanying notes 181-90 supra. 
the restrictions of political expression that may be placed on individuals and unions. The statute's regulation of unions' political contributions and expenditures is narrowly drawn in order to allow political activity funded by separate, voluntary contributions by union members.

Although the statutory restrictions on union political activities are constitutional, the leeway accorded to unions may raise constitutional questions when dissident union members are required to contribute to causes that they oppose. The Court has construed the Railway Labor Act to prevent the compulsory subsidization by union members in a union shop context of causes to which they object. In a case where such a statutory construction was unavailable, the Court found that such involuntary subsidization, sanctioned by the state, violates the members' first amendment rights. This Comment has suggested that when a union, pursuant to the NLRA, enjoys a union shop agreement or is the exclusive bargaining representative for the employees, the requisite state action is present to trigger a similar analysis for dissident union members who are represented by that union and who have made their objections known to it. In this case, however, the NLRA, like the Railway Labor Act, should be construed as not permitting such an involuntary subsidization in order to avoid a finding of unconstitutionality. If dissident members are afforded the same remedies suggested by Street, their first amendment rights will be protected at the same time that the underlying and sometimes contradictory purposes of FECA will be achieved. 